\title{
Quality and reliability of web-based information regarding restorative treatment in pediatric patients
}

\section{Purpose}

The aim of the present study is to assess the quality and reliability of web-based information about restorative treatment in pediatric patients on the internet using different scales.

\section{Materials and Methods}

Websites obtained by using keywords about restorative treatment in pediatric patients on Google and Yandex were included in the study. The study was conducted in English on a total of 440 websites. Websites were evaluated using the quality criteria for consumer health information (DISCERN toolkit), Journal of American Medical Association (JAMA) benchmarks, and Health on the Net Code of Conduct Certification (HONCode).

\section{Results}

The mean DISCERN points of the websites were moderate. Among the evaluated websites, the quality of the knowledge in $20 \%$ of the websites was low. The rate of websites with a score below 40 was $37.5 \%$. None of them has reached an excellent score. No websites met all JAMA criteria. There was no HONCode Certificate on any website.

\section{Conclusion}

This study showed that the quality of the web-based information about restorative treatment in pediatric patients was generally inadequate and scientifically imperfect.

Keywords: Internet, DISCERN, JAMA, HONCode, quality of web information

\section{Introduction}

The internet is a resource of knowledge about healthcare for both professionals and patients (1). Information technology has begun to modify the traditional medical approach from treatment towards prevention. World Health Organization declared that $71 \%$ of internet users used the internet to obtain information about health topics (2). However, there is no regulation about the content of the health issues posted, and everybody could post them online. Formerly, a person in need of dental treatment was informed by the dentist (3-5). However, nowadays, most of the patients inform themselves through the internet, even before going to the dentist.

Several different dental treatment options and dental materials are available for each case. Dentist's experience could influence the choice of treatment and materials (6). Wuollet et al. (7) stated that there were differences in the preferred materials among dentists. The different factors such as materials available, working time, tooth prognosis, material strength, co-operation, experience, and aesthetics affect dental treatment preference. Patient co-operation plays an important role in the choice of the treatment

\author{
Berna Kuter ${ }^{1} \mathbb{D}$, \\ Alp Abidin Ateşçi ${ }^{2}$, \\ Ece Eden ${ }^{3}$
}

ORCID IDs of the authors: B.K. 0000-0002-1234-8237; A.A.A. 0000-0001-6346-3801; E.E. 0000-0001-8427-0427

'Department of Paediatric Dentistry, Faculty of Dentistry, Izmir Democracy University, Izmir, Turkey

${ }^{2}$ Pedodontics, Private Clinic, Turkey

${ }^{3}$ Department of Paediatric Dentistry, Faculty of Dentistry, Ege University, Turkey

Corresponding Author: Berna Kuter

E-mail: berna.kuter@idu.edu.tr

Received: 17 October 2020

Revised: 12 January 2021

Accepted: 26 January 2021

DOI: $10.26650 /$ eor.2021812053 
and materials for the restoration of extensive primary tooth decay. However, parents generally have no idea on such factors and they try to decide which treatment is the best for their children based on what they read online. Thus, the accuracy, standard, and trustworthiness of the information on the internet are crucial (8). It was stated that many health sites included captious, inappropriate, and inaccurate information $(9,10)$. Several validation tools were developed that can assess various properties of internet sites to help to choose quality websites on health-related information. DISCERN Toolkit, JAMA Benchmarks and HONCode are some of those (11-13).

Availability of internet and easy access makes it an important tool to inform health-related issues of the population. Therefore, the purpose of this study is to assess the quality and reliability of web-based information in English websites on restorative treatment of children using different scales. The null hypothesis tested in this study is that no difference could be found among websites in terms of quality.

\section{Materials and Methods}

\section{Data gathering}

Internet search was carried out using Google and Yandex search engines. While determining the keywords, ideas of parents experiencing dental caries in their children's primary teeth, patients attending dental treatment for their children, dentists and people who has no idea about the subject were used. They were asked to suggest keywords or phrases for reaching information on treatment of deciduous teeth. Collected words and phrases were tested on several search engines before being included in the study. Then, 11 keywords were identified by excluding keywords and phrases which referred to internet sites that are not related with the subject. Keywords selected were all phrases and listed as follows: "deciduous teeth treatment(s)", "primary teeth treatment(s)", "milk teeth treatment(s)", "baby teeth treatment", "deciduous teeth restorations", "primary teeth restorations", "milk teeth restorations" and "baby teeth restorations", "primary teeth fillings", "milk teeth fillings" and "baby teeth fillings". Internet search was conducted by one pediatric dentist. The websites were evaluated between 25/03/2020 and 08/04/2020 and number of pages from Google and Yandex search engines on each keyword are presented in Table 1. The search was planned in English language on a total of 440 websites. Each keyword was searched on each search engine and the first 40 websites were assessed.

\section{Inclusion and exclusioion criteria}

Dental health centers websites, medical information websites, professional organization websites and hospital websites were included the study. The duplicate websites, links to research studies, advertisements, discussion groups, videos and images were excluded from the evaluation.

\section{The evaluation of websites}

Websites were evaluated with the DISCERN toolkit, JAMA benchmarks, and HONCode.

DISCERN toolkit: The websites were analyzed with the DISCERN toolkit (11). DISCERN tool kit includes 3 parts and 16 questions which is scored from 1 to 5 . Part 1 includes 8 ques- tions that evaluate the relevance of the publications while part 2 composed of 7 questions evaluating the quality of the information. The last part contains a question which evaluates the general quality of the website. According to the DISCERN toolkit, the total average scores of websites were divided into 5 groups as dental health-care center, informative, organizational and hospital (Table 2). The evaluator read all the information about primary teeth treatments and rated each website according to the DISCERN toolkit. Obtained data were calculated as mean score, percentages and ranges.

JAMA benchmarks: This tool was published for property standards for websites data on health by Silbergin, Lundberg, and Musacchio (12). Four main characteristics as, authorship, attribution, disclosure and currency were used as the criteria of JAMA.

Health on the net code of conduct (HONCode): This certification is maintained by an independent institution (Health on

Table 1. Keywords about restorative treatment in pediatric patients and approximate number of webpages obtained.

\begin{tabular}{|c|c|c|}
\hline Keywords & Google & Yandex \\
\hline $\begin{array}{l}\text { deciduous teeth } \\
\text { treatments }\end{array}$ & $4,390,000$ pages & 212,000 pages \\
\hline $\begin{array}{l}\text { primary teeth } \\
\text { treatments }\end{array}$ & $125,000,000$ pages & $1,000,000$ pages \\
\hline milk teeth treatments & $62,500,000$ pages & 374,000 pages \\
\hline baby teeth treatments & $190,000,000$ pages & $1,000,000$ pages \\
\hline $\begin{array}{l}\text { deciduous teeth } \\
\text { restorations }\end{array}$ & 683,000 pages & 336,000 pages \\
\hline $\begin{array}{l}\text { primary teeth } \\
\text { restorations }\end{array}$ & $2,920,000$ pages & 79,000 pages \\
\hline milk teeth restorations & $7,790,000$ pages & 783,000 pages \\
\hline baby teeth restorations & $14,500,000$ pages & 633,000 pages \\
\hline primary teeth fillings & $3,320,000$ pages & 740,000 pages \\
\hline milk teeth fillings & $1,110,000$ pages & 140,000 pages \\
\hline baby teeth fillings & $3,710,000$ pages & $1,000,000$ pages \\
\hline
\end{tabular}

Table 2. The total average DISCERN scores for different types of websites.

\begin{tabular}{|c|c|c|c|c|c|}
\hline 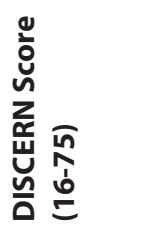 & $\begin{array}{l}\overline{0} \\
\stackrel{0}{\circ}\end{array}$ & 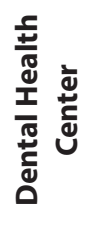 & 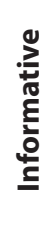 & 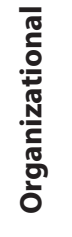 & 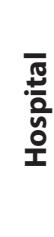 \\
\hline $\begin{array}{l}\text { Very Poor } \\
(16-26)\end{array}$ & 3 & 3 & 0 & 0 & 0 \\
\hline $\begin{array}{l}\text { Poor } \\
(27-38)\end{array}$ & 15 & 12 & 1 & 2 & 1 \\
\hline $\begin{array}{l}\text { Fair } \\
(39-50)\end{array}$ & 16 & 11 & 3 & 1 & 1 \\
\hline $\begin{array}{l}\text { Good } \\
(51-62)\end{array}$ & 6 & 2 & 4 & 0 & 0 \\
\hline $\begin{array}{l}\text { Excellent } \\
(63-80)\end{array}$ & 0 & 0 & 0 & 0 & 0 \\
\hline
\end{tabular}


the net, Lausanne, Switzerland) (13). The credibility and the property of the web data were stated on the website contained on eight standards. These are complementarity, privacy, authoritativeness, attribution, justifiability, disclosure, transparency and variations of advertisements.

\section{Statistical analysis}

The collected data from all groups were imported to Statistical Package for Social Sciences (SPSS) for Windows software, version 16.0 (SPSS Inc., Chicago, IL, USA). The frequency of each variable was calculated by descriptive statistics. All variables were analyzed for normality using the Shapiro-Wilk test. The distribution was found to be skewed. As the distribution of the data did not meet the requirements for normality and homogeneity of variances assumptions, continuous variables that belong to the websites's Discern scores were analysed by the nonparametric Kruskal-Wallis by ranks and Mann-Whitney $U$ tests for multiple and pairwise comparisons, respectively,. The chi-square test was used to compare the categorical demographic variables among the JAMA groups. The confidence interval was set to $95 \%$ and $p$ $<0.05$ was considered statistically significant.

\section{Results}

A total of 440 websites were identified and duplicate web pages, advertisements, and research articles were eliminated before evaluation. The websites considered for evaluation were dental health centres' websites (57.5\%), medical information websites $(25.0 \%)$, professional organization websites (10.0\%) and hospital websites (7.5\%). $60 \%$ of the analysed websites were originated from USA. Canada was the second country with $12.5 \%$, and Australia and India were in the third with $5.0 \%$. These countries were followed by England, Lithuania, Malta, Russia, Sri Lanka, Ukraine and Vietnam (2.5\%).

Discern Results: The DISCERN points of the websites was fair (average 40.15) (range: 23-58), and findings are presented in Table 2 . The quality of the data in $20 \%$ of the websites were low (scores of 1 and 2). The percentage of websites, with a total score of 40 and above is $62.5 \%$ and the rate of websites with a score below 40 is $37.5 \%$. No website has reached excellent score (63-80). Date of information and sources generally were not mentioned in the websites, in addition, duration, and limits of restorative treatment of children were not clear (Figure 1). References were not supplied. The scores of questions about aim, alternative treatments and benefits of treatments were presented in Table 3.

According to Kruskall-Walls test, at least one statistically significant difference between websites was found ( $p=0.034)$. Then each pair of the websites were compared by Mann Whitney U Test at 0.01 significant level. Since significant level was getting higher, 0.01 significant level was selected for each pair of the website comparisons. The scores of dental health-centre websites were higher than information websites $(p=0.005$ ). However, dental health centre websites' scores were not statistically higher than organization websites $(p=0.494)$, and hospital websites ( $p=0.315$ ). The scores of the information websites were not statistically significantly different from the hospital websites ( $p=0.499)$, and organization websites ( $p=$ 0.077 ). The scores of hospital and organization websites were

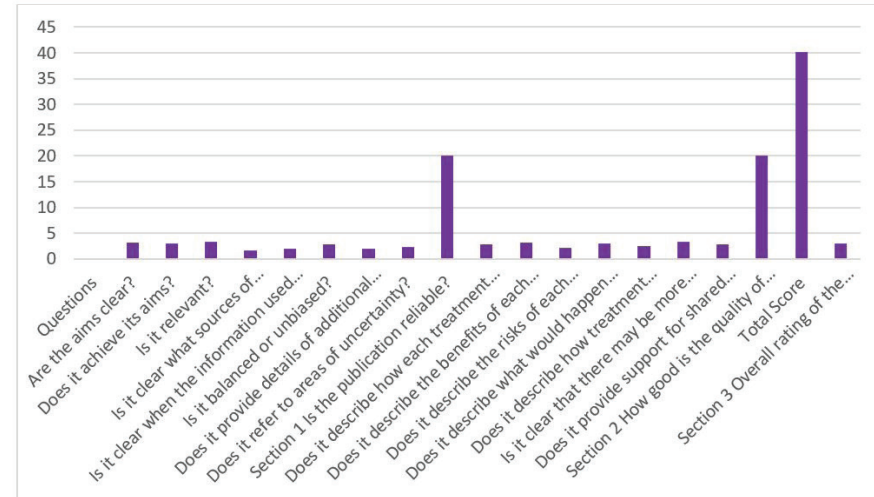

Figure 1. The Average of Questions of DISCERN Score.

Table 3. The Average and Sections DISCERN Score.

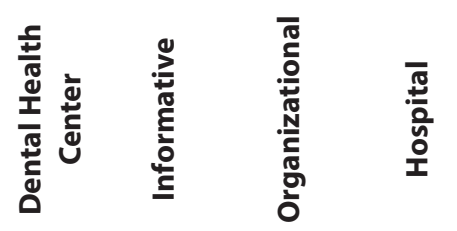

\begin{tabular}{llcccc}
\hline $\begin{array}{l}\text { Average DISCERN } \\
\text { Score }\end{array}$ & 40,15 & 38,2 & 47,6 & 39 & 37 \\
\hline $\begin{array}{l}\text { Section 1 } \\
\text { (items1-8) }\end{array}$ & 20,1 & 18,6 & 25,3 & 19,3 & 20 \\
\hline $\begin{array}{l}\text { Section 2 } \\
\text { (items 9-15) }\end{array}$ & 20 & 19,7 & 22,2 & 19,6 & 17 \\
\hline $\begin{array}{l}\text { Section 3 } \\
\text { (16. item) }\end{array}$ & 2,9 & 2,8 & 3,3 & 3 & 3 \\
\hline
\end{tabular}

not statistically significantly different $(p=0.593)$.

JAMA Results: No websites met all JAMA criteria. $30.0 \%$ of websites only met author criterion. $12.5 \%$ of them met reference criterion, $40.0 \%$ had currency criterion. No websites met disclosure criterion. $30.0 \%$ of websites displayed an author, $12.5 \%$ of websites referenced their information, none of the websites mentioned about disclosure, and $40.00 \%$ of websites displayed a date of publication.

Dental health-centre websites had high authorship JAMA points. However, there was no statistically significant difference between dental health-centre websites and the other kinds of webpages according to the authorship JAMA points. This is presented in Table $4\left(X^{2}=2.632 \mathrm{df}=1, p=0.052\right)$.

Dental health-centre websites obtained higher points $(17.5 \%)$ than the other websites in the currency JAMA criterion (Table 4). There was statistically significant difference between dental health-centre websites and the other kinds of webpages according to the currency JAMA points $\left(X^{2}=7.882 \mathrm{df}=1, p=\right.$ 0.049). There was no statistically significant difference between the scores of the websites according to the attribution JAMA criterion. $\left(X^{2}=2.159 \mathrm{df}=1, p=0.540\right)$. Organization websites had significantly lower points than the dental health-center and information websites in the currency JAMA criterion. This was presented in Figure $2\left(X^{2}=7.882 \mathrm{df}=1, p=0.049\right)$.

When the JAMA criteria scores were analysed in relation to the country of origin, the websites of Ukraine, England, Malta, Vietnamese, Lithuania did not meet any JAMA criteria (Figure 3). The websites of Russia met only currency JAMA criterion.

HonCode Results: There was no website with HonCode Cer- 
Table 4. JAMA Criteria Distribution and Comparison Between Type of Websites (\%) Chi-Square Test: ${ }^{*} p<.05$ significant difference between the groups (type of websites).

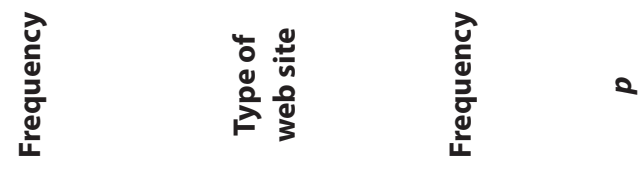

\begin{tabular}{|c|c|c|c|c|}
\hline \multirow{4}{*}{ Author } & \multirow{4}{*}{30.0} & $\begin{array}{c}\text { Dental Health } \\
\text { Center }\end{array}$ & 17.5 & \multirow{4}{*}{0.452} \\
\hline & & Information & 10.0 & \\
\hline & & Organization & 0.0 & \\
\hline & & Hospital & 2.5 & \\
\hline \multirow{4}{*}{ Attribution } & \multirow{4}{*}{12.5} & $\begin{array}{c}\text { Dental Health } \\
\text { Center }\end{array}$ & 5.0 & \multirow{4}{*}{0.540} \\
\hline & & Information & 5.0 & \\
\hline & & Organization & 2.5 & \\
\hline & & Hospital & 0.0 & \\
\hline \multirow{4}{*}{ Disclosure } & \multirow{4}{*}{0.0} & $\begin{array}{c}\text { Dental Health } \\
\text { Center }\end{array}$ & 0.0 & \multirow{4}{*}{1.00} \\
\hline & & Information & 0.0 & \\
\hline & & Organization & 0.0 & \\
\hline & & Hospital & 0.0 & \\
\hline \multirow{4}{*}{ Currency } & \multirow{4}{*}{40.0} & $\begin{array}{c}\text { Dental Health } \\
\text { Center }\end{array}$ & 17.5 & \multirow{4}{*}{0.049} \\
\hline & & Information & 15.0 & \\
\hline & & Organization & 7.5 & \\
\hline & & Hospital & 0.0 & \\
\hline
\end{tabular}

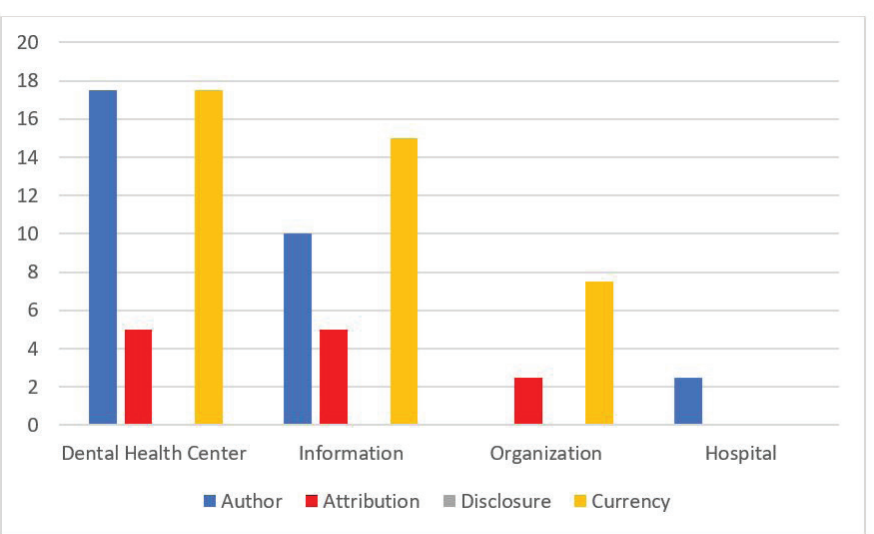

Figure 2. JAMA Criteria Scores of Websites (\%).

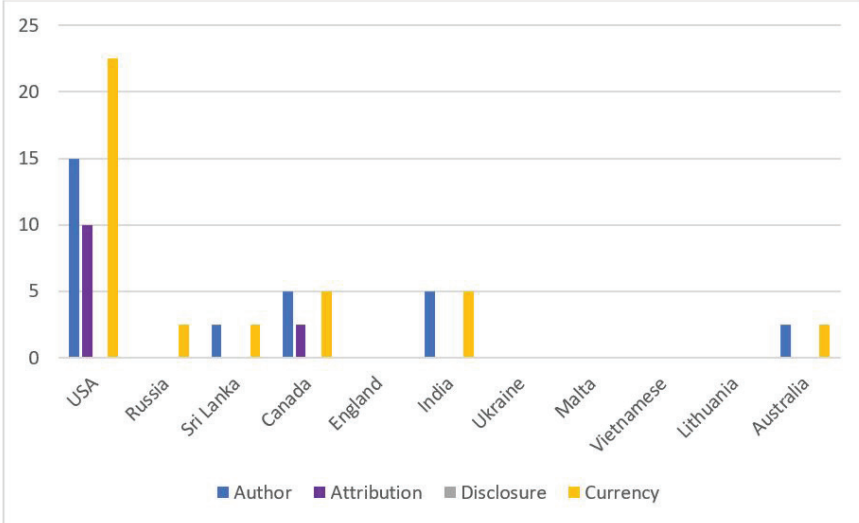

Figure 3. JAMA Criteria Scores of Countries (\%).

\section{tificate. \\ Discussion}

This study evaluated the quality of provided information related to the restorative treatment of children on internet. The findings demonstrated that the information was likely to be inadequate or incorrect. Although internet users often prefer to look at the first page, as suggested, the first available 40 websites were evaluated in two search engines for each keyword (14). Internet provides very broad information, and it is not easy to distinguish the proper informative results for the parents who are seeking help from internet. As patients' demand on learning more about the treatment possibilities from internet increased, the type of correspondence between physicians and patients changed (15). All healthcare workers started to show presence on the internet.

A previous study, evaluating the quality of oral hygiene training, reported a moderate score for quality of oral health statement available on the web (16). Similarly, the information on dental trauma on the internet was found to be limited in quantity and quality (17). It is important to guide patients and guide people on dental treatment possibilities. It was stated that dentists could provide patients with appropriate information by referring patients to approved websites, for example on the thumb sucking habit (18). When the latter was evaluated the reliability of websites on the thumb sucking habit by the DISCERN tool, the highest points obtained from 36 websites was 55 out of 80 , and the lowest points was 16 out of 80 . Baybek and Tuncer (19) evaluated the quality of information on webpages on orthognathic surgery in Turkey using the DISCERN toolkit and stated that the quality of information on orthognathic surgery on the internet was low. It was noted that higher quality information was provided by public institutions that are not concerned about profit. Stinson et al. (8) stated that high-quality internet health information was present at an appropriate reading level for youth with juvenile idiopathic arthritis and their parents. The average DISCERN scores of websites were generally poor or fair in this study. Only two dental health centers and four information websites scored good. 38 of the first 40 websites were private dental health-centre websites, 2 websites were public organizations. Private clinics had higher DISCERN scores than the others. However, both public and private websites did not score excellent in this study.

None of the websites examined includes all criteria as regard JAMA benchmarks. These results were similar to the other recent studies $(20,21)$. Dental health-center websites had a higher score than the others. This could be explained by higher currency scores. The part of disclosure scores was insufficient on all websites and public websites did not score both attribution and disclosure JAMA scores. Furthermore, author JAMA score was low in public websites.

HON is a non-governmental organization (13). It promotes a code of conduct for websites providing health information. The applicant is a direct indicator of the quality of information. However, it was shown that none of the evaluated websites had a HONCode Certificate.

The uncontrollable nature of the internet makes healthcare professionals vary in advising their patients to read more from online sources $(22,23)$. One of the main reasons for this may be an increase in websites concerning special 
implementation. These private practice websites often advertise rather than inform, and this could lead to questions in patients' minds. Thus, there is a gap that should be filled by non-profit educational institutions which publish websites with sufficient and clear information on dental health.

Based on our findings, internet information about dental restorative treatment for children is limited. The web-based information was deficient both for the reliability of the publications and the quality. English websites were searched, and it could be a limitation for this study. However, English is widely used, and we may conclude that this first research using three different methods to assess the quality of data on the webpages about restorative treatment in pediatric patients showed that the information on the topic is scarce.

\section{Conclusion}

This study showed that the quality of the web-based information about restorative treatment in pediatric patients is generally inadequate, limited, scientifically imperfect and insufficient. There is a need for a qualified web page to guide parents who are interested in dental treatment for their children.

Türkçe Özet: Pediatrik hastalarda restoratif tedavi ile ilgili web tabanli bilgilerin kalitesi ve güvenilirliği. Amaç: Internet, diş hekimleri ve hastalar için kolayca ulaşılabilir bir diş sağlığı bilgi sağlayıcısıdır. Araştırmanın amacı, internette pediatrik hastalarda restoratif tedavi ile ilgili web tabanlı bilgilerin kalitesini ve güvenilirliğini farklı ölçekler kullanarak değerlendirmekti. Gereç-Yöntem: Çocuk hastalarda restoratif tedavi ile ilgili anahtar kelimelerle Google ve Yandex arama motorları kullanılarak internet üzerinden çocukların restoratif tedavisi üzerine araştırma yapıldı. Çalışma, toplam 440 web sitesinde Ingilizce olarak yapıldı. Web siteleri, DISCERN (tüketici sağlık bilgileri için kalite kriterleri), JAMA (Amerikan Tıp Derneği Dergisi) ve HONCode (Internet Sağlık Kuralları Sertifikasyonu) kalite kriterleriyle değerlendirildi. Bulgular: Web sitelerinin ortalama DISCERN puanları orta düzeydeydi. Değerlendirilen web siteleri arasında, web sitelerinin \% 20'sinin bilgi kalitesi düşüktü. Puanı 40'ın altında olan web sitelerinin oranı \% 37,5'ti. Hiçbiri mükemmel bir puana ulaşmadı. Tüm JAMA kriterlerini karşılayan web sitesi yoktu. Hiçbir web sitesinde HONCode Sertifikası yoktu. Sonuç: Bu çalışma çocukların restoratif tedavileri ile ilgili internetteki bilgilerin kalitesini farklı ölçeklerle değerlendiren ilk araştırmadır. Bu çalışma, pediatrik hastalarda restoratif tedaviye ilişkin web tabanlı bilgilerin kalitesinin genellikle yetersiz ve bilimsel olarak eksik olduğunu göstermiştir. Ebeveynler, çocuklarının restoratf tedavisine ilişkin web sitelerindeki bilgilerin yanlışlıkları ve kısıtıııkları konusunda uyarılmalıdır. Anahtar Kelimeler: Internet, DISCERN, JAMA, HONCode, web bilgilerinin kalitesi.

Ethics Committee Approval: Not required.

Informed Consent: Not required.

Peer-review: Externally peer-reviewed.

Author contributions: BK, EE participated in designing the study. $\mathrm{BK}, \mathrm{EE}$ participated in generating the data for the study. BK, AAA participated in gathering the data for the study. BK, AAA, EE participated in the analysis of the data. BK wrote the majority of the original draft of the paper. BK participated in writing the paper. AAA has had access to all of the raw data of the study. BK and EE have reviewed the pertinent raw data on which the results and conclusions of this study are based. BK, AAA, EE have approved the final version of this paper. BK guarantees that all individuals who meet the Journal's authorship criteria are included as authors of this paper.

Conflict of Interest: The authors declared no conflict of interest.
Financial Disclosure: The authors declared that they have received no financial support.

\section{References}

1. Anderson JG, Rainey MR, Eysenbach G. The impact of CyberHealthcare on the physician-patient relationship. Journal of Medical Systems 2003;27:67-84. [CrossRef]

2. Andreassen HK, Bujnowska-Fedak MM, Chronaki CE, Dumitru RC, Pudule I, Santana S, Voss H, Wynn R. European citizens' use of E-health services: A study of seven countries. BMC Public Health 2007;7:53-60. [CrossRef]

3. Eysenbach G, Powell J, Kuss O, Sa ER. Empirical studies assessing the quality of health information for consumers on the World Wide Web: a systematic review. JAMA 2002;287:2691-700. [CrossRef]

4. Nghiem AZ, Mahmoud $Y$, Som R. Evaluating the quality of internet information for breast cancer. Breast 2016;25:34-7. [CrossRef]

5. Livas C, Delli K, Ren Y. Quality evaluation of the available Internet information regarding pain during orthodontic treatment. Angle Orthod 2013;83:500-6. [CrossRef]

6. Widstrom E, Linden J, Tiira H, Seppala TT, Ekqvist M. Treatment provided in the public dental service in Finland in 2009. Community Dental Health 2015;32:60-4.

7. Wuollet E, Tseveenjav B, Furuholm J, Waltimo-Sirén J, Valen $H$, Mulic A, Ansteinsson V, Uhlen MM. Restorative material choices for extensive carious lesions and hypomineralisation defects in children: a questionnaire survey among Finnish dentists. Eur J Paediatr Dent. 2020;21:29-34.

8. Stinson JN1, Tucker L, Huber A, Harris H, Lin C, Cohen L, Gill N, Lukas-Bretzler J, Proulx L, Prowten D. Surfing for juvenile idiopathic arthritis: perspectives on quality and content of information on the Internet. J Rheumatol 2009;36:1755-62. [CrossRef]

9. Martins EN, Morse LS. Evaluation of internet websites about retinopathy of prematurity patient education. Br J Ophthalmol 2005;89:565-8. [CrossRef]

10. Lau L, Hargrave DR, Bartels U, Esquembre C, Boufett E. Childhood brain tumor information on the Internet in the Chinese language. Childs Nerv Syst 2006;22:346-51. [CrossRef]

11. Charnock D, Shepperd S, Needham G, Gann R. DISCERN: an instrument for judging the quality of written consumer health information on treatment choices. J Epidemiol Community Health. 1999;53:105-11. [CrossRef]

12. Silberg, W. M., Lundberg, G. D., \& Musacchio, R. A. Assessing, controlling, and assuring the quality of medical information on the Internet: Caveant lector et viewor e let the reader and viewer beware. JAMA 1997;277: 1244-5. [CrossRef]

13. Baujard, V, Boyer, C, Geissbuhler, A. Evolution of health web certification through the HONcode experience. Studies in Health Technology and Informatics 2011;169: 53-7.

14. van Deursen AJ, van Dijk JA. Using the Internet: skill related problems in users' online behavior. Interacting with Computers 2009;21:393-402. [CrossRef]

15. Palmer NG, Yacyshyn JR, Northcott HC, Nebbe B, Flores-Mir C, Major PW. Canadian orthodontist Internet user profile. Angle Orthod 2006;76: 92-7.

16. Verhoef WA, Livas C, Delli K, Ren Y. Assessing the standards of online oral hygiene instructions for patients with fixed orthodontic appliances. JADA 2015;146:310-7. [CrossRef]

17. Ghazaleh SA, Hassona Y, Hattar S. Dental trauma in social media-Analysis of Facebook content and public engagement. Dental Traumatology 2018;34:394-400. [CrossRef]

18. Shital KDP, Bargale S, Pandya P, Bhatt K, Barad N, Shah N, Venkataraghavan K, Ramesh K. Evaluation of Health on the Net seal label and DISCERN as content quality indicators for patients seeking information about thumb sucking habit. J Pharm Bioallied Sci. 2015;7:481-5. [CrossRef] 
19. Bavbek NC, Tuncer BB. Information on the Internet Regarding Orthognathic Surgery in Turkey: Is It an Adequate Guide for Potential Patients? Turkish J Orthod 2017;30: 78-83.

20. Passos K. K, Leonel A. C, Bonan P. R, Castro J. F, Pontual M. L., Ramos-Perez F. M \& Perez, D. E. Quality of information about oral cancer in Brazilian Portuguese available on Google, Youtube, and Instagram. Medicina Oral, Patologia Oral, Cirugia Bucal 2020;25:346-52. [CrossRef]

21. Leira Castelo-Baz P, Pérez-Sayáns, M., Blanco, J, \& LorenzoPouso, A. I. Available patient-centered Internet information on peri-implantitis. Can our patients understand it? Clinical Oral Investigations 2019;23:1569-74. [CrossRef]

22. Aldairy T, Laverick S, Mclntyre GT. Orthognathic surgery: is patient information on the internet valid? Eur J Orthod 2012;34:466-9.

23. de Boer MJ, Versteegen GJ, van Wijhe M. Patients' use of the Internet for pain-related medical information. Patient Educ Couns 2007;68:86-97. [CrossRef] 